\title{
Utilization of and research on fungi in Poland
}

\section{MAKSYM NIKONOROW}

\author{
NIKONOROW, M. 1978: Utilization of and research on fungi in Poland. - Karstenia 18 \\ (supp|.). \\ Ingathering of mushrooms growing in a wild state is very popular in Poland. Their sale as \\ raw fresh or dehydrated material as well as marinades is under supervision of Health \\ Service according to the regulations beeing in force. These regulations define 31 species \\ which are admitted circulation and manufacturing but not in the mixture. For drying only \\ 15 out of 31 . \\ Widespread using of mushrooms comport with health education of people collecting \\ them and handing performed by the Sanitary-Epidemiological Stations in the aim to prevent \\ poisonings, e.g. by organizing mushroom displays. \\ The scientific literature in this field is connected with epidemiology of poisoning \\ and methods for laboratory diagnosis e.g. identification of spores in the suspected \\ material (poisonings). \\ Many species of home mushrooms were investigated on the nutritional value including \\ vitamins, macro- and microelements, aminoacids, phosphatides and antibacterial substances. \\ within the framework of the hygienic evaluation the microflora and pesticide residues \\ of mushrooms were investigated, too. \\ The principles for preparation and storage of dried mushrooms were established taking \\ into consideration the influence of drying on the level of some vitamins.
}

N. Nikonorow, National Institute of Hygiene, Polish Academy of Sciences, ul. Chominsha 24, 00-791 Warsaw, Poland.

Crops of forest fungi in Poland amount to 9000 tons in years of heavy yield (22). Both fresh and processed fungi are inspected in purchasing centres of the Forest Production Association of Enterprises "LAS" ("Forest") and in each processing plant. All these units are also supervised by the health service.

The inspection is performed by specialists specially trained for this purpose. They are responsible for recognition of edible species and evaluation of their quality.

In Poland 49 sanitary-epidemiological stations and 200 field stations operating within the health service system have supervision over foods and their production. The Department of Food Research, National Institute of Hygiene, is the competent body that controls the activities of all the stations and establish guidelines of their research work and their monitoring investigations.

According to the regulations in force (23) based on the present Polish Food Law issued in 1970 (first act was issued in 1928) 31 species of fungi are accepted for sale and processing. Among them are 15 species of Boletus, two species of honey fungus (Armizlaria melzea), tooth fungus (Hydnum) and morel (Morchella), as well as four species of mushroom (Agaricus), edible species of agaric (Lactarius deliciosus), chantarelle (Canthareilus cibarius) and others. of them only 15 species can be dried and processed to fungal meal (Table 1 ).
Mixtures of fresh fungi, or of stems with addition of fungi cut into pieces, or mixtures in which the number of stems is higher than the number of caps cannot be accepted for sale or processing. This undoubtedly protects against possible mistakes and failures in detecting toxic species in the mixture, and at the same time it facilitates the recognition of the species which quite often is difficult or even impossible when fungi are divided into parts in the mixture. Fresh fungi are sold loose from the counter or baskets, and dried rungi in transparent packaging or in characteristic strings.

All phases of processing, starting with sorting through packaging, storing and transporting, are supervised by the health service. In 1969-1975, 1873 samples were examined in one voivodship and one third of them were collected from the production plants (10). Poland exports forest fungi according to the Recommended European Regional Standard for Fresh Fungus "Chantarelle" (Contharellus cibarius) and four other standards elaborated by the Joint FAO/WHO Food Standards Programme, Codex Alimentarius Commission CAC/RS 38 - 1970, 39 - 1970, 40 - 1970, CAC/RCP 4/5 - 1971 and CAC/RS 55 - 1972 .

Research on the nutritive value of domestic fungi was initiated by the Department of Food Research in the National Institute of Hygiene. It covered the following species of Fungi: Gyromitra esculenta (Pers.) Fr., Boletus edulis Fr., Cantharellus cibarius 
Table 1. The fungi permitted in Poland for food

$\begin{array}{ll}\text { Agarious bisporus } & \begin{array}{l}\text { Macrolepiota procera* } \\ \text { A. campestris }\end{array} \\ \text { A. hortensis } & \text { Morchella conica } \\ \text { A. sihaticus } & \text { M. rotunda } \\ \text { Armillariella mellea* } & \text { Rozites caperata } \\ \text { Boletus edulis* } & \text { Sarcodon imbricatum* } \\ \text { Cantharellus cibarius }^{*} & \text { Suillus bovinus* } \\ \text { Craterellus cornucopioides }^{*} & \text { S. elegans } \\ \text { Gyroporus castaneus }^{*} & \text { S. flavidus } \\ \text { G. cyanescens } & \text { S. granulatus } \\ \text { Hydnum repandum } & \text { S. luteus* } \\ \text { Lactarius deliciosus } & \text { S. variegatus* } \\ \text { Leccinum aurantiacum } & \text { Tricholoma flavovirens* } \\ \text { L. duriusculum } & \text { Xerocomus badius } \\ \text { L. scabrum } & \text { X. chrysenteron } \\ & \text { X. subtomentosus* }\end{array}$

* Also dried and as a meal product

Fr. and Agaricus bisporus Lange, Tricholoma flavovirens (Fr.) Lund., Armillarielza mellea (Fr.) Karst., Macrolepiota procera (Fr.) Sing. and Lactarius vellereus (Fr.) Fr.In many species the content and digestibility of nitrogenous compounds were determined, taking into account the presence of chitin. This is an insoluble and non-protein compound containing $6.5 \%$ of nitrogen. Following the investigations (in vitro and in vivo) another conversion coefficient for nitrogen and protein was suggested. Instead of 6.25 taking into account $16 \%$ of nitrogen in the animal protein, this coefficient should be equal to 4.034.45 taking Boletus and Helvezla as examples (7-9). It was found that the digestibility of fungal proteins is similar to that of other plant proteins. G. esculenta is a poorer source of protein and nitrogenous compounds than $B$. edulis, but both show similar digestibility of the nitrogenous fraction (9).

Scleroderma aurantium L. ex Pers. (4, 20) was the subject of chemical investigations, 57 species of fungi belonging to Basidiomycetes family (5) of biological ones, and $G$. esculenta (14) of toxicological investigations.

Glucose, fructose and mannose were identified in scleroderma. Sterols were found in its ether extract and indole derivatives in its alcoholic extract. Since similar indole derivatives occur in Psilocybe fungi, this may indicate toxicological significance of $s$. aurantium. Alanine, arginine, o-aminobutyric acid and aspartic acid as well as asparagine, glutamic acid,leucine, serine, tyrosine and valine were also identified $(5,20)$.

Biological investigations referred to antibacterial activity. Staphylococcus pyogenes var. aureus 209 P and Escherichia coli were test organisms. The strongest inhibition of growth of $S$. aureus was shown by Marasmius scorodonius (Fr.) Fr. and it has been found to have a most pronounced antibacterial activity ( 5 ).

The toxicological investigation of Gyromitra indicated a low acute toxicity of dried fungus for rats and dogs. Fresh fungus administered directly in the form of water browing and after removal of protein, and also in the form of dried fungi several months after drying, confirmed that the dried fungus may be used for consumption after 6 months' storage (14). Later investigations of this fungus were made in the Sanitary-Epidemiological Station of the Division of Food and Nutrition in Katowice. The studies were based on observations of toxic symptoms such as irritation of the upper respiratory tract, corestasis and hyperemia of conjunctiva in workers employed in drying the Gyromitra. Investigations on animals in similar conditions revealed changes in the respiratory system, small or extensive extravasation of blood into the pulmonary tissue and haemorrhages into the kidneys. In the distillates and methanol extracts of the fruiting bodies and spores and also in the condensate of the vapour from a drying machine, the presence of the same reducing compounds was found. Among them gyromitrine as well as products of its oxidation or disintegration and methyl formyl hydrazine were identified ( 1 ).

In the previous preliminary toxicological studies of Paxillus involutus (Fr.) Fr. it was revealed that boiling in water removes toxic substances only to a certain extent. When extracted in the Soxhlet apparatus they all pass into methanol and slightly less into ethanol. Chloroformic, acetone, benzene and ether (ethyl and petroleum) extracts were not toxic, while the residues after extraction with these solvents caused significant changes in the animals' organs. They were not observed when animals were given the material previously extracted with methanol. In the methanol extract from the fraction of non-protein nitrogenous compounds 12 free amino acids, 8 volatile amines with water vapour including mono-, di- and trimethylamine, guanine, xanthine, hypoxanthine and adenine were identified and histamine, choline, acetylcholine, betaine and muscarine were isolated (12, 13).

Apart from these comprehensive toxicological and chemical studies carried out in the Department of Bromatology, Institute of Environment Studies and Bioanalysis, Pharmaceutical Faculty of the Medical Academy, Lódź, a generous amount of nitrogen, protein, nitrogenous non-protein compounds soluble and insoluble in water (chitin) as well as indispensable amino acids were determined in numerous species of edible fungi. In the majority of cases methionine is a limiting amino acid. This was confirmed by the biological investigations on animals. Only the protein of E.edulis is of biological value.

The carbohydrate content (20-30\% of dry matter) and fat fraction (3-8\%) were studied. In the phospholipid fraction of Leccinum scabrum (Fr.) S.F. Gray and $L$. aurantiacum (Fr.) S.F. Gray palmitic and linolic 
acids were found and serine instead of choline (18). The level of mineral compounds was equal to $6.5-12.3 \%$ d.m. and it was in the following sequence: $\mathrm{P}, \mathrm{Ca}, \mathrm{Fe}$, $\mathrm{Cu}, \mathrm{Mn}, \mathrm{Zn}, \mathrm{As}$, Co.

A method for tentative determination of chloro -organic pesticides applied once for forest protection was elaborated as well as a method for evaluation of the health quality of dried fungi and fungal meal by means of determination of the contents of uric acid, which is the catabolite of insects (15).

The riboflavin content was compared in several species of fresh fungi and after scalding. Submersion of fungi in water at $90-95^{\circ} \mathrm{C}$ caused loss of vitamin in c. cibarius reaching up to $32 \%$ and to about. $60 \%$ in Suillus luteus (Fr.) S.F. Gray (16).

On basis of the vitamin contents determined by other authors in Poland (3) one can find some similarities between fungi and fresh vegetables. Four species under study (Table 2) may be the source of vitamins. The largest amounts of thiamine, riboflavin and calciferol were found in Boletus, and carotene only in c. cibarius.

Data on the identification of amino acids in the nrotein of s. luteus. A. mellea, Tricholoma georgii and $L$. vellereus were also obtained in other research centres (24).

The nutritive value, mineral and fat substances as well as amino acid contents were investigated in Hydnum (Sarcodon) imbricatum L. ex. Fr. (17). Water and ethanol extracts of this fungus showed mitodepressive and antimitotoxic activities which are ascribed by the authors to polysaccharides (19).

The microbiological requirements for standardization were suggested on the basis of studies of 14 species of dried fungi and 8 kinds of fungal meal of various compositions. They anticipate the absence of $E$. coli in 0.001 anaerobic sporogenic bacteria and mould (neither mycelium nor hyphae) (2).

Concluding this brief review of studies carried out in Poland, I wish to draw attention to papers on fungus poisonings caused by mistaking toxic for edible fungi $(6,21)$ and to remind of the probably already known epidemiological and chemical studies of Grzymala carried out over 20 years ago. The role of Grzymala in the development of this branch of science in Poland is undoubtedly quite significant. The studies were related to poisoning with Cortinarius orellanus syn. Agaricus calliseus, Dermocybe orellana. It grows in the period from mid-August to mid-November in coniferous and mixed forests, usually at the border of Poznan and Bydgoszez voivodships (6). The fungus is not high $(5-9 \mathrm{~cm})$ and has a cap of cinnamon and foxy colour, diameter $5-8 \mathrm{~cm}$, with a hummock at the top. Its gills are wide and loose and slightly lighter in colour.

Toxication with this fungus is characterized by a long incubation period of 3 to 14 days and by the following symptoms: intense thirst, and dryness and a burning sensation in the oral cavity. The patient usually drinks over ten litres of liquids per day. Symptoms develop gradually. They are disturbances in the alimentary tract, nausea and vomiting, constipation, headaches, convulsions, loss of consciousness. Death due to toxuria may occur after several weeks. Recovery may take several months.

This fungus produces a thermostable substance readily soluble in the alkali, quite easily in methanol and poorly in water, and showing reducing properties. Grzymala obtained it in the amount of 1.0-1.2 g out of $100 \mathrm{~g}$ of dried fungus with a capacity of about $40 \%$. One fruiting body contains about $15-20 \mathrm{mg}$ of this substance. The lethal dose $\left(L D_{50}\right)$ for cats is $4.9 \mathrm{mg} / \mathrm{kg}$, for mice and guinea pigs about $8 \mathrm{mg} / \mathrm{kg}$. The substance does not haemolyze and agglutinate blood cells and it probably cumulates in the organism. It was named orellanine.

During the recent National Meeting of Mycologists in Lódź in September 1977 four basic trends of studies in Poland were presented: chemistry and toxicology, processing, cultivation of highly selected species, and ecology. It is quite obvious that the health aspect dominates in these studies, as is also expressed by the research work in the field of laboratory diagnosis of fungus poisoning. These studies are usually carried on by the Sanitary-Epidemiological Station in Poznań

Table 2. Mean contents of thiamine, riboflavin, ergocalciferol and carotene in $100 \mathrm{~g}$ of fresh edible fungi prepared as a dish

\begin{tabular}{|ll|c|c|c|c|c|}
\hline Kind of fungi & & $\begin{array}{c}\text { Thiamine } \\
\mu \mathrm{g}\end{array}$ & $\begin{array}{c}\text { Riboflavin } \\
\mu \mathrm{g}\end{array}$ & $\begin{array}{c}\text { Ergocalci- } \\
\text { ferol I.U. }\end{array}$ & $\begin{array}{c}\text { Carotenoides } \\
\mu \mathrm{g}\end{array}$ & $\begin{array}{c}\text { Carotene } \\
\mu \mathrm{g}\end{array}$ \\
\hline Cantharellus cibarius & mean & 34 & 125 & 89.2 & 713 & 448 \\
& range & $22-51$ & $43-228$ & $60-100$ & $642-748$ & $410-477$ \\
Boletus edulis & mean & 275.8 & 993 & 120.7 & 0 & 0 \\
& range & $197-525$ & $592-1564$ & $100-150$ & 0 & 0 \\
Tricholoma & mean & 86.5 & 157.7 & 31 & 26.4 & - \\
flavovirens & range & $57-102$ & $70-232$ & $25-40$ & - & - \\
Leccinum scabrum & mean & - & - & 112.5 & 0 & 0 \\
& range & - & - & $100-125$ & 0 & 0 \\
\hline
\end{tabular}


co-operating with the Institute of Environment Studies and Bioanalysis and with the Institute of Occupational Medicine in Lódź. Recent analyses and observations confirmed, however, the periodicity of poisoning intensification at several years intervals, but these periods do not always correspond with the years of high fungus crops. It has also been observed that greater numbers of fungus species are being picked by people for consumption purposes. This seems to prove increased knowledge of edible species of fungi. Unfortunately this is not followed by a reduction in cases of poisoning. They are related mainly to confusing Amanita phalloides with wild mushrooms and also to insufficient caution on the part of fungus pickers. It also happens that various edible species are not picked at all in certain regions of the country.

It is quite obvious that education in this field, begun in childhood, through publications, coloured atlases and exhibitions organized by sanitary-epidemiological stations as well as collective mushroom picking organized by institutions play a very important part in the promotion of principles of how to differentiate toxic and edible species and how to pick fungi properly. This is also related to the protection of the natural environment - a problem of increasing significance year by year.

It may be assumed that the research work initiated by the National Institute of Hygiene and continued mainly by the Department of Bromatology, Institute of Environment studies and Bioanalysis, Lódz, and also by the Sanitary-Epidemiological Station in Poznań will now develop in the Academy of Agriculture in Poznań, Medical Academy in Kraków and Department of Experimental Studies of "LAS" Enterprise. This enterprise plays a very important part in supplying the home market with forest fungi and in fungus processing and export. It also pays much attention to research work in this field and participates in all related activities (11).

\section{References}

1. Biskupek,H.1971:Badanie zatrué przemyslowych piestrzenica kasztanowata Gyromitra esculenta (Pers.) Fr. na przykladach zaobserwowanych w Polsce.Bromat. Chem. Toksykol. 4: 319, 373.

2. Cylkowska, R. \& Pollok, M. 1976: Ustalenie wskazników mikrobiologicznych dla grzybów suszonych i maczki grzybowej.-Bromat. Chem. Toksykol. 9: 485 .

3. Grekowicz, M. et al. 1952: Zawartość witaminy $B_{1}$, $\mathrm{B}_{2}$, D i karotenu (prowitaminy A) w grzybach jadalnych. - Przem. Rol. i Spoz. 6: 379.

4. Grzybowska, J. 1967: Krajowe grzyby trujace cz. II. Wolne aminokwasy $w$ tegoskórze pospolitym (Scleroderma aurantium L.). - Roczn. Panstwowego Zakl. Hig. 18: 581 .

5. Grzybowska, J. \& Karkocha, I. 1968: Substancje antybakteryjne w niekt6rych gatunkach grzybów należacych do Basidiomycetes. - Roczn. PZH 19: 395.

6. Grzymala, S. 1958, 1961: Smiertelne zatrucia rzekomo -jadalnym gatunkiem grzyba. - Roczn. PZH 9:
115,$277 ; 12: 363,491$.

7. Karkocha, I. 1964: Badania wartości odzywczej gaski zielonki (Tricholoma equestre Fr. Quel.) i opieńki miodowej (Armillariella mellea Fr. Kumm.). - Roczn. PZH 15: 312.

8. -"- 1968, 1969: Badania zawartości i strawnosci zwiazków azotowych $w$ grzybach Lepiota procera (Scop. ex. Fr.), Lactarius vellerus Fr. Roczn. PZH 19: 307; 20: 267.

9. Karkocha, I. \& Mlodecki, H. 1962, 1964, 1965: Badania nad wartościa odzyweza niektórych grzybów krajowych. - Rocsn. PZH 13: 473; 15: $27 ; 16: 71$.

10. Klawitter, M. \& Szmid, M. 1975: Ocena grzybów suszonych znajdujacych sie w obrocie handlowym na terenie województwa poznańskiego. Bromat. Chem. Toksykol. 8: 192.

11. V Krajowy Zjazd Mikrobiologiczny w Lodzi, 22-23. IX. 1977. Streszczenie.

12. Lasota, W. 1970: Badania chemiczne krowiaka podwinietego, Paxillus involutus (Batsch) Fr. - Zesz. Nauk. Bromatol. Chem. Toksykol. 3: 9.

13. Lasota, W. et al. 1965, 1966, 1967, 1968: Badania nad krowiakiem podwinietym (Paxillus involutus Batsch. Fr.) - Acta Polon. Pharm. 22: 521; 23: 75; 24: 71; 25: 334 .

14. Mlodecki, H. et al. 1962: Badania toksykologiczne piestrzenicy jadalnej (Gyromitra esculenta). - Roczn. PZH 13: 483.

15. Mlodecki, H. et al. 1972: Kwas moczowy jako wskaßnik jakości zdrowotnej suszów grzybowych. - Bromat. Chem. Toksykol. 5: 487.

16. Mlodecki, H. et al. 1973: Wplyw blanszowania grzybów na zawartość ryboflawiny. - Bromat. Chem. Toksykol. 6: 261.

17. Mlodecki, H. et al. 1973: Badania w zwiazku z ocena higieniczna sarniaka dachówkowatego Hydnum (Sarcodon) imbricatum L. ex. Fr. Bromat. Chem. Toksykol. 6: 41, 297.

18. Mlodecki, H. et al. 1972, 1973: Sklad fosfatydów w niektórych gatunkach grzybów. - Bromat. Chem. Toksykol. 5: 1; 6: 264.

19. Molik-Wegiel, J. 1974, 1976: Badania aktywności biologicznej grzyba wielkoowocnikowego Sarcodon imbricatum przy zastosowaniu testów fitobiologicznych. - Bromat. Chem. Toksykol. 7: $215 ; 9: 195$.

20. Nikonorow, M. et al, 1967: Krajowe grzyby trujace cz. I. Badania chemiczne tegoskóra pospolitego (Scleroderma aurantium). - Roczn. PZH 18: 277.

21. Raszeja, St. 1954: O śmiertelnych zatruciach grzybami ze szczególnym uwzglednieniem diagnostyki sadowo lekarskiej. - Patol. Pol. 5(2).

22. Rocznik statystyczny GUS, 1975 str. 308.

23. Rozporzadzenie Ministra z dnia 10 stycznia $1959 \mathrm{r}$ w sprawie nadzoru sanitarnego nad obrotem grzybami i przetwórstwem grzybów (Dz. U. nr. 5 , poz. 34).

24. Szymczak, J. 1962: Sklad aminokwasowy bialek grzybów jadalnych. - Roczn. PZH 13: 467. 